\title{
Emergency department overcrowding as a threat to patient dignity
}

\author{
Rick Mah, MD
}

Version française à la page $\mathbf{3 7 0}$

E mergency department (ED) overcrowding is the subject of intense study to evaluate its causes and consequences. However, although implied, there is little mention of the threat that overcrowding poses to patient dignity. This threat is intuitively obvious to health care providers and patients in the ED, yet it is elusive to prove, as there is neither a universally accepted definition of dignity nor a method to measure it. We must, therefore, look to areas such as palliative care, practice guidelines and human rights to help define and quantify the impact of overcrowding on patient dignity. Dignity is a cornerstone of humanity, and as physicians we have a moral obligation to our patients, colleagues and ourselves to preserve and promote it. Patient dignity may represent a new area of research in ED overcrowding and greater awareness could improve patient care and satisfaction. More importantly, overcrowding as a threat to patient dignity could be a powerful motivator to engage others beyond the ED to respond to this crisis.

\section{BASIC CONCEPTS}

The Oxford Dictionary defines dignity as the "state of being worthy of honour and respect." In the classical sense, dignity is attributed to an individual as a result of distinction or excellence; whereas in Judeo-Christian tradition, all humans have inherent dignity because they are "made in the image of God." Kant argued a similar inherent worth based simply on our capacity for rational autonomy. ${ }^{2}$ Following World War II, dignity gained prominence as a fundamental principle in numerous national constitutions and international declarations, most notably the Universal Declaration of Human Rights. ${ }^{3}$ Despite its central role in these documents and in society, definitions vary depending on the "cultural and subcultural contexts," tradition will be discussed in this article.

\section{DIGNITY AND HEALTH CARE}

Dignity figures prominently in many professional codes of ethics, yet there is little practical guidance for the practitioner. ${ }^{5}$ Concept analyses suggest that dignity with care contains the values of "autonomy, truth, justice, and responsibility to human rights," ${ }^{6}$ and is demonstrated by "attentiveness, awareness, personal respect, engagement, fraternity and an active defense of the patient." One article from the emergency medicine literature defined dignity's attributes as respect, autonomy, empowerment and communication. ${ }^{8}$ Unfortunately, these attributes suffer the same ephemeral status as the term they attempt to define. The purpose of this article is not to enter into an abstract discussion, but rather to consider dignity tangibly from the perspective of that which can be promoted, lost, threatened or violated.

\section{DIGNITY PROMOTING MODELS}

Models in palliative care and in practice guidelines that promote dignity attempt to bridge the gap between the concept of care with dignity and actual patient care. Chochinov's ${ }^{9}$ dignity-conserving model for palliative care describes factors that influence patient dignity and an approach to preserving dignity in the clinical setting. Areas that are negatively impacted by overcrowding, as a result of limited space and time for patient care, include symptom distress like poor pain control, ${ }^{10,11}$ patient autonomy, privacy concerns ${ }^{12,13}$ and care tenor. ${ }^{14}$

From the Department of Emergency Medicine, Montreal General Hospital, Montréal, Que.

All editorial matter represents the views of the authors and not necessarily those of CJEM or the Canadian Association of Emergency Physicians. 
Another attempt to provide guidelines of care with dignity comes from the British National Health Service, which has enumerated factors and benchmarks for privacy and dignity, as well as indicators for achieving best practice. ${ }^{15}$ Despite this, the experience from British inpatient wards ${ }^{16}$ suggests that patient privacy and dignity fall short of these recommendations, and these settings are likely more hospitable than overcrowded EDs.

\section{VIOLATIONS OF DIGNITY IN THE ED}

Schachter ${ }^{17}$ argued that a violation of human dignity can be recognized, even though the abstract term cannot be defined: "I know it when I see it even if I cannot tell you what it is." Whereas Mann ${ }^{18}$ proposed a taxonomy of 4 types of dignity violations: 1) being ignored or insufficiently acknowledged; 2) being seen, but only as a member of a group; 3) having one's personal space transgressed involuntarily; and 4) humiliation. Qualitative studies of patient experiences in the ED and in corridors suggest that overcrowding threatens dignity based on privacy breaches ${ }^{19}$ and inappropriate care tenor. ${ }^{20,21}$ However, the true power of these studies lies in the patient narratives; as it is in their own words that the violation to their dignity becomes palpable. In the case of dignity, generalizing experiences for the sake of evidence dilutes the gravity of the individual experience, which by Mann's taxonomy could itself represent a dignity violation (i.e., being seen, but only as a member of a group). Without recognition of the affront to the dignity of the patient as a person, we further dehumanize the crisis in our EDs. Some patient narratives may help us to regain our perspective:

"I was hospitalized with heart problems, but I was kept lying out in the hall. Because I could not stand, the main problem was using the toilet. It is not very pleasant to lie on the bedpan in a hall ... I lay there with my noises and smells in front of the entire assembly ... for me it was painful and humiliating." 19

"For the first days, I felt like a nobody because I was lying in the corridor. I had severe pain and felt very sick. People and nurses walked past the entire time without looking at me ... There were 11 of us out in the corridor."19

An elderly patient who was unable to urinate in the bedpan because of her position and surroundings stated, "[The nurse said] 'I can't be bothered with this ... I'm putting a nappy on you' ... it really destroyed me. The thought of having to put a nappy on and be told to go [urinate] in that. I mean they can't make you here they are making you ..."20

\section{DIGNITY AND HUMAN RIGHTS}

Another framework in which to study how ED over- crowding threatens dignity is a human rights-based approach. Because dignity is one of the foundational concepts of human rights, "these rights can be analyzed and defended as being necessary for the protection or promotion of human dignity." ${ }^{22}$ Two rights that are threatened as a result of overcrowding are the right to health and the right to be free from torture or cruel, inhuman or degrading treatment or punishment.

Article 12 of the International Covenant on Economic, Social and Cultural Rights recognizes the right to enjoy the highest attainable standard of physical and mental health. ${ }^{23}$ This right implies protection from "bodily harm, unnecessary morbidity and preventable mortality," ${ }^{24}$ and ED overcrowding likely puts patients at risk for all of these threats. An association has been demonstrated between overcrowding and compromised patient care, such as suboptimal pain control ${ }^{10,11}$ and delays to time-sensitive treatment (e.g., thrombolytics for myocardial infarction) ${ }^{25}$ and antibiotics for pneumonia. ${ }^{26,27}$ Poor outcomes, such as increased cardiovascular complications, ${ }^{28,29}$ a higher risk of pneumonia ${ }^{30}$ and longer admissions $^{31,32}$ have also been associated with overcrowding. Other studies have suggested that ED overcrowding can increase the risk of death. ${ }^{33-35}$ The right to health also includes the right to prevention, treatment and control of disease, ${ }^{23}$ and overcrowding increases the risk of contagious illnesses because of understaffing ${ }^{36}$ and the close proximity of patients to each other. ${ }^{37}$ One of the most sobering examples of this danger was the SARS epidemic, in which "the presence of a single unrecognized SARS patient in one crowded emergency department created the epicenter of an outbreak." 38

Article 7 of the International Covenant on Civil and Political Rights prohibits torture and cruel, inhuman or degrading treatment or punishment. ${ }^{39}$ Recognized methods of torture include temperature extremes, sleep deprivation, sensory bombardment with noise or light, denial of privacy and acts of humiliation..$^{40,41}$ Although many, if not all, of these conditions exist to some degree in EDs, overcrowding is not torture, as the definition of torture requires the treatment to be intentional and to cause severe suffering. ${ }^{42}$ However, these conditions could be considered cruel, inhuman or degrading and could fail to meet norms that exist to protect other vulnerable populations. The Sphere Project ${ }^{43}$ recommends at least $3.5 \mathrm{~m}^{2}$ of covered floor area per person to provide dignified accommodation in refugee camps. In an overcrowded ED, the area per patient can approach $2 \mathrm{~m}^{2}$ when stretchers are placed side by side. The Geneva Conventions, which protect prisoners of war 
and civilians in times of war, state that the living conditions must be adequately lighted, heated and spacious, and at night individuals "must have the conditions of darkness which would be most beneficial for their rest." ${ }^{44,45}$ Similar norms exist to protect civilian prisoners. ${ }^{46}$ Using these minimum standards as a point of reference, ED overcrowding puts patients at risk of inhuman and degrading treatment and, thus, threatens their dignity (Table 1).

\section{FUTURE DIRECTIONS}

The extensive literature on health and human rights and humanitarian medicine may hold valuable lessons for emergency medicine. Heightened awareness of the threats to patient dignity provides the opportunity to improve communication, promote autonomy and address privacy concerns, in part, with ED design and organization. The impact of overcrowding on patient dignity should be studied directly rather than extrapolating from non-ED sources. Dignity in the ED could be measured based on the models set out by Chochinov and the British National Health Service, but also, more quantifiably, based on health outcomes (i.e., the right to health) and minimum standards. By addressing dignity in the ED in the broadest sense as outlined in this article, not only would health outcomes be expected to improve, but also patient satisfaction.

\section{CONCLUSION}

Despite being an abstract concept, dignity may represent a powerful agent of change because of its universality and its ability to unify, empower and personalize. Health care providers and administrators may be more compelled to act if overcrowding is perceived as a humanitarian or public health crisis, rather than simply an ED problem. A human rights perspective may be more accessible to the public and help build support for public policy changes to combat overcrowding. As health

Table 1. Threats to patient dignity due to emergency department overcrowding

\begin{tabular}{|c|c|c|}
\hline Threat & Factors & Examples \\
\hline \multirow{10}{*}{$\begin{array}{l}\text { Cruel, inhuman, degrading treatment: } \\
\text { failure to meet minimum standards }\end{array}$} & \multirow[t]{5}{*}{ Shelter } & Insufficient personal space \\
\hline & & Inadequate ambient temperature \\
\hline & & Excessive noise and light \\
\hline & & Sleep deprivation \\
\hline & & Acts of humiliation \\
\hline & Food and water & Inadequate access \\
\hline & \multirow[t]{2}{*}{ Personal hygiene } & Inadequate access \\
\hline & & Acts of humiliation \\
\hline & \multirow[t]{2}{*}{ Security } & Risk of harm \\
\hline & & Psychological distress \\
\hline \multirow[t]{8}{*}{ Threat to right to health } & \multirow[t]{2}{*}{ Needless suffering } & Symptom distress (e.g., inadequate pain control) \\
\hline & & Psychological distress \\
\hline & \multirow[t]{3}{*}{ Preventable morbidity } & $\begin{array}{l}\text { Delays to time-sensitive treatment (e.g., thrombolytics, } \\
\text { antibiotics) }\end{array}$ \\
\hline & & $\begin{array}{l}\text { Poor outcomes (e.g., cardiovascular complications, } \\
\text { increased risk of pneumonia) }\end{array}$ \\
\hline & & Prolonged hospital stay \\
\hline & Preventable mortality & Increased risk of death \\
\hline & \multirow[t]{2}{*}{ Transmission of infectious disease } & MRSA \\
\hline & & SARS \\
\hline \multirow[t]{6}{*}{ Failure to preserve and promote dignity } & \multirow[t]{4}{*}{ Inappropriate care tenor } & Patient being ignored or insufficiently acknowledged \\
\hline & & Patient being treated without respect or understanding \\
\hline & & Acts of humiliation \\
\hline & & $\begin{array}{l}\text { Failure to promote patient autonomy (paternalism, lack of } \\
\text { informed consent) }\end{array}$ \\
\hline & \multirow[t]{2}{*}{ Privacy violations } & Confidentiality violations \\
\hline & & Failure to protect patient modesty \\
\hline
\end{tabular}


care providers in the ED, we cannot allow ourselves to forget our humanity; nor can we allow humanity to be forgotten by institutions or society.

Acknowledgements: The author would like to thank Dr. Scott Delaney, Dr. Alison Doucet, Dr. Kenneth Doyle and Dr. Kathleen Glass for their invaluable input, support and encouragement.

Competing interests: None declared.

Keywords: emergency department, overcrowding, dignity, human rights

\section{REFERENCES}

1. Soanes C, Stevenson A, Eds. The Oxford Dictionary of English. Oxford (UK): Oxford University Press; 2005.

2. Schulman A. Bioethics and human dignity. President's Council on Bioethics: Staff Working Paper. 2005. Available: www .bioethics.gov/background/human_dignity.html (accessed 2009 May 20).

3. Universal Declaration of Human Rights, UNGA Res. 217A, 3rd Sess., 1948.

4. Shultziner D. Human dignity - functions and meanings. Global Furist Topics 2003;3:3. Available: www.bepress.com/gj /topics/vol3/iss3/art3 (accessed 2009 May 20).

5. Canadian Medical Association. CMA code of etbics [policy]. Ottawa (ON): The Association; 2004. Available: http://policy base.cma.ca/PolicyPDF/PD04-06.pdf (accessed 2009 May 20).

6. Coventry ML. Care with dignity: a concept analysis. 7 Gerontol Nurs 2006;32:42-8.

7. Soderberg A, Gilje F, Norberg A. Dignity in situations of ethical difficulty in intensive care. Intensive Crit Care Nurs 1997;13:135-44.

8. Griffin-Heslin VL. An analysis of the concept of dignity. Accid Emerg Nurs 2005;13:251-7.

9. Chochinov HM. Dignity-conserving care - a new model for palliative care. JAMA 2002;287:2253-60.

10. Hwang U, Richardson L, Sonuyi T, et al. The effect of emergency department crowding on the management of pain in older adults with hip fracture. J Am Geriatr Soc 2006;54:270-5.

11. Pines JM, Hollander J. Emergency department crowding is associated with poor care for patients with severe pain. Ann Emerg Med 2008;51:1-5.

12. Karro J, Dent AW, Farish S. Patient perceptions of privacy infringements in an emergency department. Emerg Med Australas 2005;17:117-23.

13. Moskop JC, Marco CA, Larkin GL, et al. From Hippocrates to HIPAA: privacy and confidentiality in emergency medicine - part II: challenges in the emergency department. Ann Emerg Med 2005;45:60-7.

14. Larsen B, Skretting P, Farstad T. Patients in corridorsconsequences for quality of care and patient integrity [article in Norwegian]. Tidsskr Nor Laegforen. 2000;120:2636-8.

15. Essence of care. Patient-focused benchmarks for clinical governance. London (UK): Department of Health; 2003. p. 119-128. Avail- able: www.dh.gov.uk/en/Publicationsandstatistics/Publications /PublicationsPolicyAndGuidance/DH_4005475?IdcService=GE T_FILE\&dID=29341\&Rendition=Web (accessed 2008 May 20).

16. Woogara J. Patients' rights to privacy and dignity in the NHS. Nurs Stand 2005;19:33-7.

17. Schachter O. Human dignity as a normative concept. $A m$ J Int Law 1983;77:848-54.

18. Mann J. Dignity and health: The UDHR's revolutionary first Article. Health Hum Rights 1998;3:30-8.

19. Foss C, Krogstad U. Invisible patients - experiences of lying in a corridor [article in Norwegian]. Tidsskr Nor Laegeforen 2000;120:2639-41.

20. Coughlan M, Corry M. The experiences of patients and relatives/significant others of overcrowding in accident and emergency in Ireland: a qualitative descriptive study. Accid Emerg Nurs 2007;15:201-9.

21. Wellstood K, Wilson K, Eyles J. "Unless you went in with your head under your arm": patient perceptions of emergency room visits. Soc Sci Med 2005;61:2363-73.

22. Chaskalson A. Human dignity as a constitutional value. In: Kretzmer D, Klein E, editors. The concept of buman dignity in buman rights discourse. Netherlands: Kluwer Law International; 2002. p. 133-44.

23. International Covenant on Economic, Social, and Cultural Rights, Res. 2200A, UNGA, 21st Sess., 1966. Available: www.un hchr.ch/html/menu3/b/a_cescr.htm (accessed 2009 May 20).

24. The right to the bighest attainable standard of health. Substantive issues arising in the implementation of the international covenant on economic, social and cultural rights, GC 14, Economic and Social Council. Committee on Economic, Social and Cultural Rights, 22nd Sess., 2000, E/C.12/2000/4.

25. Schull MJ, Vermuelen M, Slaughter G, et al. Emergency department crowding and thrombolysis delays in acute myocardial infarction. Ann Emerg Med 2004;44:577-85.

26. Fee C, Weber E, Maak C, et al. Effect of emergency department crowding on time to antibiotics in patients admitted with community-acquired pneumonia. Ann Emerg Med 2007; 50:501-9.

27. Pines JM, Locallo AR, Hollander J, et al. The impact of emergency department crowding measures on time to antibiotics for patients with community-acquired pneumonia. Ann Emerg Med 2007;50:510-6.

28. Pines JM, Hollander J. The impact of emergency department crowding on cardiac outcomes in ED Patients with potential acute coronary syndromes [abstract]. Ann Emerg Med 2007;50:S3.

29. Dierks DB, Roe M, Chen A. Prolonged emergency department stays of non-ST-segment elevation myocardial infarction patients are associated with worse adherence to the American College of Cardiology/American Heart Association Guidelines for Management and Increased Adverse Events. Ann Emerg Med 2007;50:489-96.

30. Carr BG, Kaye A, Wiebe D, et al. Emergency department length of stay: a major risk factor for pneumonia in intubated blunt trauma patients. 7 Trauma 2007;63:9-12.

31. Liew D, Liew D, Kennedy MP. Emergency department length of stay independently predicts excess inpatient length 
of stay. Med J Aust 2003;179:524-6.

32. Richardson DB. The access-block effect: relationship between delay to reaching an inpatient bed and inpatient length of stay. Med J Aust 2002;177:492-5.

33. Sprivulis PC, Da Silva JA, Jacobs IG, et al. The association between hospital overcrowding and mortality among patients admitted via Western Australian emergency department. Med J Aust 2006;184:208-12.

34. Richardson DB. Increase in patient mortality at 10 days associated with emergency department overcrowding. Med J Aust 2006;184:213-6.

35. Chalfin DB, Trzeciak S, Likourezos A, et al. Impact of delayed transfer of critically ill patients from the emergency department to the intensive care unit. Crit Care Med 2007;35:1477-83.

36. Henderson DK. Managing methicillin-resistant staphylococci: a paradigm for preventing nosocomial transmission of resistand organisms. Am J Med 2006;119(6A):S45-52.

37. Kibbler CC, Quick A, O'Neill AM. The effect of increased bed numbers on MRSA transmission in acute medical wards. J Hosp Infect 1998;39:213-9.

38. Schull MJ, Redelmeier D. Infection control for the disinterested. CMAJ 2003;169:122-3.

39. International Covenant on Civil and Political Rights, Res. 2200A, UNGA, 21 st Sess., 1966. Available: www.unhchr.ch/html /menu3/b/a_ccpr.htm. (accessed 2009 May 20).

40. Leave no marks: enhanced interrogation techniques and the risk of criminality. Cambridge (MA): Physicans for Human Rights; 2007. Available: http://physiciansforhumanrights.org/library /report-2007-08-02.html (accessed 2009 May 20).

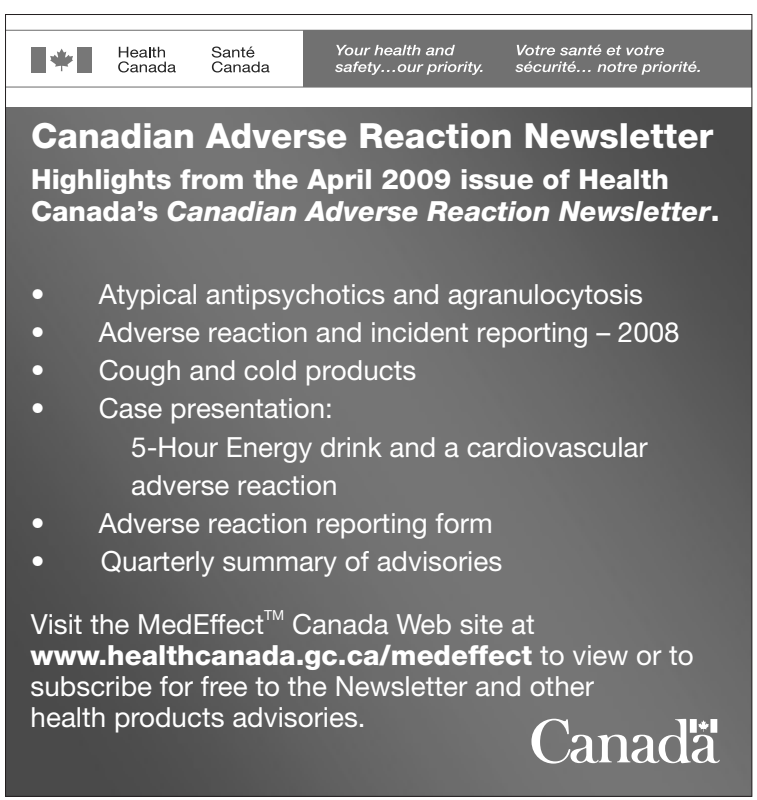

41. Interrogations, torture and ill treatment: legal requirements and bealth consequences. Cambridge (MA): Physicians for Human Rights; 2004. Available: http://physiciansforhumanrights.org /library/documents/reports/iraq-medical-consequences-of.pdf (accessed 2009 May 20).

42. Convention against torture and other cruel, inhuman or degrading treatment or punishment, Res. 39, UNGA, 46th Sess., 1984. Available at: www.unhchr.ch/html/menu3/b/h_cat39.htm (accessed 2009 May 20).

43. Sphere handbook humanitarian charter and minimum standards in disaster response. The Sphere Project; 2004. Available: www .sphereproject.org/handbook/pages/navbook.htm?param1=0 (accessed 2009 May 20).

44. International Committee of the Red Cross. Convention relative to the protection of civilian persons in time of war. Geneva $(\mathrm{CH})$ : The Committee; 1949, Article 85. Available: www.icrc.org /ihl.nsf/WebART/380-600095?OpenDocument (accessed 2009 May 20).

45. International Committee of the Red Cross. Convention relative to the treatment of prisoners of war. Geneva $(\mathrm{CH})$ : The Committee; 1949, Article 25 P3. Available: www.icrc.org/ihl.nsf /COM/375-590032? OpenDocument (accessed 2009 May 20).

46. First United Nations Congress on the Prevention of Crime and the Treatment of Offenders Standard Minimum Rules for the Treatment of Prisoners, Res. 663C, UN, 24th Sess., 1955. Available: www.unhchr.ch/html/menu3/b/h_comp34.htm (accessed 2009 May 20).

Correspondence to: Dr. Rick Mah, Montreal General Hospital, 1650 Cedar Ave., Montréal QC H3G 1A4; rick.mah@mcgill.ca 